\title{
Maçaranduba neles! Torcidas organizadas e policiamento no Brasil
}

\author{
Marcos Alvito[1]
}

\author{
Para Simoni Lahud Guedes, craque do NEPESS (Núcleo \\ de Estudos e Pesquisas sobre Esporte e Sociedade), \\ pioneira da antropologia do futebol no Brasil
}

\begin{abstract}
Resumo
A primeira parte do artigo analisa a bibliografia acerca das torcidas organizadas no Brasil. A segunda examina as contribuições da bibliografia à luz de uma pesquisa etnográfica desenvolvida a respeito do policiamento no Brasil, contrastando de maneira crítica os resultados com as observações da bibliografia atualmente existente.
\end{abstract}

Palavras-chave: violência no futebol; torcidas organizadas; policiamento.

\section{¡Maçaranduba en ellos! Torcidas organizadas y policía en el Brasil}

\section{Resumen}

La primera parte del artículo analiza la bibliografía acerca de las torcidas organizadas en el Brasil. La segunda examina las contribuciones de la bibliografía a la luz de una investigación etnográfica desarrollada respecto al control policial en el Brasil, contrastando de manera crítica los resultados con las observaciones de la bibliografía actualmente existente.

Palabras clave: violencia en el fútbol; torcidas organizadas; control policial.

\section{Maçaranduba! Organized cheer and Police in Brazil}

\section{Abstract}

The first part of the article presented a bibliographic analysis of groups of soccer fans that are called "torcidas organizadas" in Brazil. The second part was dedicated to a critical comparison between what the bibliography states about policing and the lessons of fieldwork in Brazil.

Keywords: soccer violence; soccer fans; policing.

\section{Maçaranduba! Supporters organisés et la Police pour le football au Brésil}

\section{Résumé}

La première partie de larticle est dédiée à une analyse de la bibliographie sur les ultras au Brésil. Dans la seconde partie j'examine les contributions de cette bibliographie sous la lumière d'une recherche ethnographique à propos du maintient de l'ordre au Brésil, en confrontant de manière critique les conclusions de cette étude avec les observations de la bibliographie actuelle.

Mots-clés: football et violence; ultras; mantient de l'ordre. 


\title{
Entrando em campo
}

Foi uma chegada triunfal. Os dois ônibus da torcida $A,{ }^{1}$ devidamente escoltados por uma viatura do Grupamento Especial de Policiamento em Estádios (GEPE), ${ }^{2}$ aproximaram-se dos arredores do estádio ao som de fogos de artifício lançados pela janela do coletivo. Assim que estacionaram, os ônibus foram cercados pelos policiais do GEPE, tendo à frente o oficial responsável. Ao início, confiscaram-se os "morteiros" (fogos de artifício) e começou uma discussão entre um soldado e um rapaz alto e forte. $\mathrm{O}$ oficial interrompeu aos gritos avisando que ali quem manda é ele. Com "voz de comando", colocou para dentro dos ônibus os torcedores que já haviam saído. Foi permitido que descessem inicialmente apenas os torcedores que tinham ingressos. Um a um, eles desceram, levantaram a camisa, sofreram revista pessoal e de todos seus pertences. O desavisado antropólogo começou a tirar fotos de todo o processo, sendo confundido alternativamente com um repórter ou, o que é bem pior e mais perigoso, com um espião da polícia. Isto fez com que alguns torcedores passassem a gesticular ameaçadoramente, e outros me recomendaram que fosse fotografar a torcida do outro time. Começava assim, de forma pouco auspiciosa, meu trabalho de campo com uma das mais antigas torcidas organizadas do Brasil e, no dizer da própria, "a mais temida".

Após quatro meses, foi possível inverter a minha posição diante daquele grupo de torcedores. Agora estava embarcando em um ônibus da própria torcida novamente em direção à Volta Redonda para um jogo "clássico". Depois de horas de espera, dois dos ônibus alugados não chegaram, ou melhor, o motorista de um deles foi embora assim que percebeu se tratar de uma torcida organizada. Um terceiro transporte, com alguns componentes da torcida vindos de Niterói apareceu, e foi nele em que viajamos, devidamente seguidos por uma viatura do GEPE. Um ex-dirigente da torcida - uma das pessoas que haviam me mostrado o dedo médio alguns meses antes — recomendou-me explicitamente sentar nos primeiros assentos do ônibus: "vai sentadinho na frente, professor, vai na frente". Sábia sugestão. Assim que entrei, um rapaz sentado uma fileira atrás colocou o rosto para fora da janela e começou a xingar a todos, dirigindo impropérios aos homens e comentários obscenos às mulheres. $\mathrm{O}$ que mais me admirou foi a raiva demonstrada por ele, a verdadeira fúria com que ele agrediu verbalmente os passantes. Em seguida, todos os torcedores dentro do ônibus começaram a cantar:

\author{
Torcida louca, \\ Cheira, cheira, cheira, \\ Cheira sem parar, \\ Fuma, fuma, fuma, \\ Fuma sem parar \\ Torcida louca.
}

Na estrada, os novatos do grupo foram levados aos fundos do ônibus e passaram por um "batizado", que consta alternativamente de tapas e gritos, além de

\footnotetext{
PPor motivos que ficarão óbvios no texto, nomeou-se torcida A, podendo apenas dizer que é uma das principais torcidas de um dos quatro grandes clubes do Rio de Janeiro. A partida ocorreu no Estádio da Cidadania, Volta Redonda, em setembro de 2005.

2É um destacamento especial da Polícia Militar do Rio de Janeiro, criado em 1991 e atualmente subordinado ao Batalhão de Polícia de Choque, com aproximadamente 70 homens.

${ }^{3}$ Jogo entre dois clubes de expressão e que são rivais de um longo período. Embora haja exceções, no Brasil os clássicos mais importantes dão-se entre clubes da mesma cidade ou, no máximo, do mesmo estado.
} 
visitas ao banheiro, onde são amontoados diversos adolescentes. ${ }^{4}$ Um deles, ao sair das instalações sanitárias, parecia estar com o braço quebrado e passou o restante da viagem com uma expressão aterrorizada de choro contido. Ele improvisou uma tipoia com o próprio casaco.

Aos gritos, alguém pediu que o motorista ligasse a televisão. Ao saber que não transmitia nenhuma programação, apenas exibia DVDs, a pessoa sentada a meu lado tentou arrancar o aparelho, porém foi aconselhado a fazer isso "na volta". Também lhe foi dito que aquela é a única companhia de transportes que atualmente lhes aluga veículos, o que pareceu demover o rapaz do seu propósito. À altura da Baixada Fluminense, o coletivo parou em frente à Favela do Lixão e mais 30 torcedores embarcaram, agravando a superlotação. Os veteranos passaram a recolher contribuições "voluntárias" dos calouros (e também do etnógrafo) para a compra de cerveja. Aos urros, ordenou-se ao motorista que parasse em um posto de gasolina. Além de Cannabis, passou-se a consumir cerveja. Além disso, uma pessoa resolveu lançar uma lata de cerveja em um travesti que mostrava seus dotes à beira da estrada. Houve também um engarrafamento inesperado. De vez em quando uma música animava o ambiente: "torcida A, a ordem do dia agora é matar".

\section{O desavisado antropólogo começou a tirar fo- tos de todo o processo, sendo confundido alter- nativamente com um repórter ou, o que é bem pior e mais perigoso, com um espião da polícia}

Ao longo da viagem, com o dobro do tempo normal, foi impossível ouvir qualquer comentário sobre o jogo daquela noite, a colocação do clube no campeonato, ou a respeito de um determinado jogador. Logo, não escutei, em mais de três horas de viagem, ninguém conversar sobre futebol. Contaram-se histórias de outras excursões, como a que ocorrera há algumas semanas: não conseguiram chegar até Santos (os ônibus foram detidos pela polícia paulista), mas, "roubamos tudo, comemos pra caralho!". Outro sujeito detalhou suas aventuras e proezas sexuais, e alguns relembraram uma verdadeira antologia dos piores momentos da violência policial.

No entanto, o que mobilizou fortemente a todos foram histórias de conflitos com as outras torcidas organizadas. A antagonista principal daquele dia era a torcida B, vista como torcida de "playboy", isto é, de jovens brancos de classe média, chamados de "bambis". Alguém diz ter observado passar o carro de escolta da torcida B com policiais contratados, que teriam mostrado as "peças" (ou seja, as armas). Há um intenso debate sobre como e quando vai ocorrer o confronto com "os playboy". Em certo momento, um rapaz acreditava que mexeram em

\footnotetext{
4Para uma análise da viagem como momento excepcional de afrouxamento das regras e acerca do "batizado", ver Rosana da Câmara Teixeira, Os perigos da paixão: visitando jovens torcidas cariocas, São Paulo, Annablume, 2003, p. 116-119. Em uma perspectiva menos etnográfica e mais de análise da bibliografia (inclusive internacional) sobre as viagens dos torcedores, ver "Da aventura: caravanas e narrativas de viagem", In: Bernardo Buarque de Hollanda, O clube como vontade e representação: o jornalismo esportivo e a formação das torcidas organizadas de futebol no Rio de Janeiro, 7 Letras, 2009, p. 407-485.
} 
sua mochila e começou a ameaçar o outro torcedor. Com exceção de um apavorado etnógrafo, todos tomaram o partido e alguns se levantaram das poltronas, lotando o corredor de jovens ameaçando-se uns aos outros, à beira de uma conflagração geral que viria a ser trágica naquelas condições. Uma voz salvadora, da única mulher presente em meio a uns 80 homens, elevou-se no tumulto de vozes: "Chegamos! Chegamos!". Imediatamente todos começaram a cantar animadamente a música da torcida, como se nada tivesse acontecido.

Novamente encontramos os policiais do GEPE à espera. Preocupado em evitar a possibilidade de um confronto com os torcedores adversários, o oficial no comando nos colocou para dentro do estádio, onde fomos revistados separadamente. O primeiro tempo da partida já havia transcorrido, e o clube perdia por um a zero. Ao chegarmos à arquibancada, fico impressionado com a energia com que a torcida A entoava suas músicas:

\section{Sendero luminoso sangue bão, eu sou da Torcida A, sou da torcida do clube $A$}

A chegada da torcida A "incendiou" o estádio, dando outra animação à torcida do clube. As letras das músicas estabeleciam associações bizarras, fazendo referência à guerrilha peruana, ou com uma coreografia estilo punk de pulos, empurrões e socos simulados entre eles mesmos: " $\tilde{A}, \tilde{a}, \tilde{a}$, a Torcida A é Talibã". Certamente há outras piores, afirmando que a torcida A "dá porrada em todo mundo", é o "terror do Rio". Há ainda aquelas que desafiam a torcida adversária, de forma irônica: "Torcida B pequenininha, cabe numa kombizinha" ou obscena: "Torcida B vem chupar meu pau". Mas o etnógrafo é surpreendido e fica emocionado quando ouve a torcida A cantar:

\section{Ô, o clube Aéminha vida, o clube Aé minha história, oclube Aé meu amor}

\section{Primeiro tempo: a morte como desafio}

Não será discutida aqui a possível análise da "viagem" como rito de passagem para os neófitos e momento excepcional de desregramento e afirmação das hierarquias no interior da torcida. ${ }^{5}$ Acredita-se que este episódio demonstra a complexidade presente no estudo das torcidas organizadas.

Por um lado, é inegável que tais organizações constituem uma espécie de 'clube da luta' aos jovens dispostos a praticar o que José Miguel Wisnik chamou de "um esporte radical de pobres [...] para os quais a inclusão em uma torcida e seus emblemas, em batalha campal com a torcida outra, faz mais sentido do que os torneios simbólicos do jogo". ${ }^{6}$ De outro, as torcidas organizadas são o motor da festa nas arquibancadas,

\footnotetext{
${ }^{5} \mathrm{O}$ mencionado ex-presidente da torcida A relatou que o mais comum seria haver dois ônibus, o primeiro somente com a diretoria e o pessoal com mais "disposição", os chamados "guerreiros". No outro iriam os mais jovens na torcida e/ou os "bobões", pessoal que não é propriamente de briga.

6José Miguel Wisnik, Veneno remédio: o futebol e o Brasil, São Paulo, Companhia das Letras, 2008, p. 54.
} 
com seus instrumentos de percussão, suas canções de incentivo ao time ou provocação aos adversários, ${ }^{7}$ sua coreografia, suas bandeiras de diversos tamanhos, temas e efeitos especiais. ${ }^{8}$ Sem elas o ambiente no estádio ficaria bem menos vibrante. Ademais, é necessário salientar alguns pontos para eliminar a ideia de que as mesmas sejam apenas um "bando de marginais", como costumam ser apresentadas na imprensa.

Para começar, é preciso lembrar que seu surgimento deu-se em finais da década de 1960, momento de grande ebulição política das juventudes mundial e brasileira. ${ }^{9}$ Sendo assim, muitas das primeiras 'organizadas' tinham a palavra 'jovem' ${ }^{10}$ no nome e eram bastante contestatórias do status

\author{
O que mobilizou fortemente a todos foram his- \\ tórias de conflitos com as outras torcidas orga- \\ nizadas. A antagonista principal daquele dia \\ era a torcida B, vista como torcida de "playboy"
}

quo clubístico e político, ${ }^{11}$ protestando contra dirigentes, reivindicando o rebaixamento do preço dos ingressos ou organizando boicotes aos jogos. Um dos pioneiros na pesquisa das torcidas organizadas e da violência no futebol, o sociólogo Maurício Murad, afirmou que, no interior das organizadas, "os violentos, brigões ou arruaceiros" são apenas $5 \%$ do total dos integrantes. ${ }^{12}$ Por se tratar de um jogo fora do Rio de Janeiro, a duas horas de onibus, estavam ali somente os integrantes mais hard da torcida, uma espécie de "batalhão de choque" de uma torcida assumidamente e reconhecidamente violenta. ${ }^{13}$ Desse modo, não se deve generalizar este comportamento para todas as torcidas organizadas.

\footnotetext{
${ }^{7}$ Há diversas canções: algumas são reservadas unicamente para os momentos em que a torcida está em um espaço reservado, sem a presença de outros torcedores; outras para serem cantadas nos estádios

${ }^{8}$ Como queima de fogos, sinalizadores luminosos, apitos, fumaça de diversas cores, balões, placas formando mosaicos gigantes, bolas de ar coloridas etc. Atualmente, vários destes itens (ou mesmo todos) são proibidos em determinados estádios.

9Para uma exaustiva, erudita e brilhante história da formação das torcidas organizadas no Rio de Janeiro, com menções a de outros estados (sobretudo São Paulo), consulte Bernardo Buarque de Hollanda, O clube como vontade e representação: o jornalismo esportivo e a formação das torcidas organizadas de futebol no Rio de Janeiro, 7 Letras, 2009. Para um texto mais sintético, ver "A festa competitiva: formação e crise das torcidas organizadas entre 1950 e 1980", In: Bernardo Buarque de Hollanda, João M.C. Malaia, Luiz Henrique de Toledo, Victor Andrade de Melo, A torcida brasileira, Rio de Janeiro, 7 Letras, 2012, p. 70-121.

${ }^{10}$ No Rio de Janeiro: Torcida Jovem do Flamengo (1967, inicialmente chamava-se Poder Jovem), Torcida Jovem do Botafogo (1969), Força Jovem do Vasco (1970), Young Flu (1970); em São Paulo: Torcida Jovem do Santos (1969), Torcida Jovem Camisa 12 (1971) e muitas outras por todo o Brasil como, por exemplo, a Torcida Jovem do Grêmio (1977). Ver Bernardo Buarque de Hollanda, op. cit., p. 50-52, e a segunda parte do livro, intitulada "O drama do Jornal dos Sports e a formação das Torcidas Jovens".

"No segundo semestre de 1978, quando a campanha pela Anistia ainda engatinhava, a Gaviões da Fiel fez o primeiro ato público durante um jogo contra o Santos. Após a queima de fogos, desfraldaram uma faixa pedindo a "Anistia ampla, geral e irrestrita". A Polícia Militar agiu imediatamente, mas os corintianos, dando-se os braços, protegeram a faixa. ${ }^{12}$ Maurício Murad, Futebol e violência no Brasil”, Pesquisa de Campo, n. 3/4, Rio de Janeiro, 1996, p. 101. Mais recentemente, o mesmo autor atualizou estes números para 5 a 7\%, segundo pesquisa realizada em 2009/10, ver Maurício Murad, A violência no futebol, São Paulo, Saraiva, 2012, p. 30.

${ }^{13}$ Em uma visita à sede da torcida A, um dos integrantes de uma subdivisão reclamou da carência de brigões, ou seja, "só temos 20 guerreiros na pista, o resto é bobão".
} 
Reduzir o fenômeno das organizadas à violência resulta em um empobrecimento da compreensão. Em uma etnografia meticulosa e sensível, a antropóloga Rosana da Câmara Teixeira mostra a teia de reciprocidade existente entre estes jovens, que vivenciam seu pertencimento a uma torcida organizada como uma paixão, no sentido de uma entrega generosa e total, ancorada no sentimento de fidelidade e dedicação ao grupo. ${ }^{14}$ A luta, neste caso, une o grupo contra os adversários e serve de teste, representando uma 'obrigação moral'.

Autor de outra notável etnografia, desta vez focalizando as torcidas de São Paulo, Luiz Henrique de Toledo já havia chegado a uma conclusão semelhante, a saber: no futebol, e, sobretudo, entre as torcidas, sociabilidade e conflito são as faces de uma mesma moeda. No dizer do antropólogo, em termos de sociabilidade, o futebol:

opõe e agrega, alegra e entristece, une e separa, estabelece diferenças e semelhanças, cria situações de confraternização e conflito, que transcendem o perímetro determinado pelas linhas do gramado. ${ }^{15}$

É fundamental perceber, para além do senso comum, a violência como um elemento constitutivo do futebol, que à maneira da briga de galos em Bali é uma forma de "brincar com o fogo, porém sem o risco de se queimar".16 Arlei Damo, um dos muitos pesquisadores de futebol a fazer aproximações com o texto de Geertz, salienta o fato do "futebol espetáculo" ${ }^{17}$ ser um jogo disjuntivo, que tem como objetivo estabelecer vencedores e perdedores, ${ }^{18}$ mas não somente isso:

Tampouco é a vitória, pura e simples, que interessa aos torcedores. O que os cativa é o drama inerente à possibilidade de ganhar e perder junto com o time vinculado ao clube, que representa uma comunidade afetiva. ${ }^{19}$

\footnotetext{
${ }^{14}$ Rosana da Câmara Teixeira, Os perigos da paixão: visitando jovens torcidas cariocas, São Paulo, Annablume, 2003. p. 178.

${ }^{15}$ Luiz Henrique Toledo, Torcidas organizadas de futebol, Campinas, São Paulo, Autores Associados, ANPOCS, 1996, p. 103. Para etnografias mais recentes, inclusive dando conta da formação dos grupamentos de torcedores que negam a qualificação de torcidas organizadas, ver duas interessantes dissertações: Isabella Trindade Menezes, Entre a Fúria e a Loucura - Análise de duas formas de torcer pelo Botafogo Futebol e Regatas, Dissertação de Mestrado em Memória Social, Rio de Janeiro, UNIRIO, 2010; Francisco Carvalho dos Santos Rodrigues, Amizade, trago e alento: a Torcida Geral do Grêmio, da rebeldia à institucionalização. Dissertação de Mestrado em História, Niterói, Universidade Federal Fluminense, 2012. Outros trabalhos que merecem menção: Tarcyane Cajueiro Santos, Dos espetáculos de massa às torcidas organizadas: paixão, rito e magia no futebol, São Paulo, Annablume, 2004; Carlos Alberto Máximo Pimenta, Torcidas organizadas de futebol - violência e auto-afirmação, Taubaté, Vogal Editora, 1997. Embora não dedique muitas páginas às torcidas organizadas, a segunda parte do livro de Hilário Franco Jr. é importante para contextualizá-las, ver "Parte 2. Futebol, metáfora do mundo contemporâneo", In: $A$ dança dos deuses: futebol, sociedade, cultura, São Paulo, Companhia das Letras, 2007.

${ }^{16}$ Clifford Geertz, "Um jogo absorvente: notas sobre a briga de galos balinesa”, In: __ _. A interpretação das culturas, Rio de Janeiro, Guanabara, p. 308.

${ }^{17}$ Ele distingue quatro matrizes futebolísticas: escolar, comunitária (campeonatos de várzea), 'bricolada' (peladas, jogos com regras combinadas ad hoc) e espetacularizada, que vem a ser o futebol profissional. Ver Arlei Sander Damo, Do dom à profissão: a formação de futebolistas no Brasil e na França, São Paulo, Aderaldo \& Rothschild, ANPOCS, 2007, p. 33-51.

${ }^{18}$ Mesmo quando ocorre um empate, há uma discussão interminável entre os torcedores para apontar aquele que deveria ter vencido ou, ao menos, que saiu do confronto em vantagem (caso das equipes que conseguem empatar um jogo que estavam perdendo até quase o final).

${ }^{19}$ Arlei Sander Damo, op. cit., p. 49.
} 
O amor ao clube é uma mola propulsora que funciona como 'máscara social. ${ }^{20}$ Essa identidade clubística é contrastiva e, portanto, intrinsecamente conflituosa, embora, idealmente, trate-se de um confronto marcado somente pela violência simbólica e não literal. A simbologia tem caráter fortemente masculino, supondo a submissão sexual do adversário expressa em inúmeros cantos e expressões. ${ }^{21}$

Vale citar a contribuição essencial de José Miguel Wisnik, ao lembrar que "os jogos de bola catalisam violências acumuladas e potenciais, chamando -as sobre si, ora exacerbando-as, ora diluindo-as".22 Por ser um jogo aberto ao investimento de significados, o futebol serve para expressar oposições e rivalidades de variadas naturezas: políticas, religiosas, sociais, étnicas, culturais etc. Nas palavras de Wisnik: ${ }^{23}$

o futebol é um instrumento de elaboração de diferenças, um campo festivo e polêmico de diálogo não verbal, projetado no terreno da disputa lúdica, que atualiza a necessidade de que haja um outro para que eu seja, de que um outro me afirme ao me negar.

Para tal autor, no caso das organizadas, desapareceriam as "mediações simbólicas" e o "outro", ao invés de ser condição contrastiva da minha existência (torcer para um time é ser rival de outros), passa a ser negado, visando-se, in extremis, a sua eliminação (o que por vezes ocorre literalmente) ${ }^{24}$ Caberia aqui lembrar um dos cantos mais famosos de uma conhecida torcida carioca: "Torcer, lutar, o inimigo massacrar". Numa visita à sede da torcida A, notei um plástico colado na janela, com o lema de uma torcida aliada: "Queremos a guerra, pois só ela trará a paz com a destruição dos nossos inimigos". Em seu mural, havia o seguinte recado: "A nossa moral é superior, assumimos a morte como desafio".

Embora eu tenha voltado fisicamente incólume da minha incursão etnográfica, não posso deixar de registrar que dois anos depois um dos torcedores daquele ônibus veio a ser espancado em plena rua por duas torcidas rivais, falecendo em virtude de um traumatismo craniano.

De qualquer forma, ao invés de perceber a violência das torcidas como fruto de patologias individuais ou coletivas, é preciso entendê-la como uma linguagem e se perguntar sobre a razão de, no Brasil, milhares de jovens escolherem pertencer a estes grupos. Murad relaciona a violência dos estádios (e em torno deles) com o alto grau de ilegalidade existente

\footnotetext{
${ }^{20}$ Arlei Sander Damo, “Futebol e estética”, São Paulo em Perspectiva, vol. 15, n. 3, 2001, p. 87-88.

21“Metemos cinco neles", "eles tomaram de quatro", "a bola tá lá dentro", e muitos cantos impublicáveis de torcidas organizadas em que há uma verdadeira obsessão pela sodomização do adversário. A outra face da moeda consiste no futebol ser uma das poucas esferas do mundo social que permite aos homens se reunirem "numa atmosfera mista de cumplicidade e de disputa", "difusamente homossexual" segundo José Miguel Wisnik, Veneno remédio: o futebol e o Brasil, São Paulo, Companhia das Letras, 2008, p. 59. A jornalista e crítica feminista Julie Burchill vai além. Ela acredita que o ódio dos torcedores às mulheres dos jogadores deve-se ao "desejo homoerótico" deles por seus ídolos. Burchill on Beckham, London, Yellow Jersey Press, 2001, p. 90

22José Miguel Wisnik, op. cit., p. 43

23/bidem, p. 51.

24/bidem, p. 53. Mauricio Murad aponta o Brasil como campeão mundial de mortes de torcedores: foram 42 na década entre 1999-2008, uma média de mais de quatro mortos por ano. Maurício Murad, $A$ violência no futebol, São Paulo, Saraiva, 2012, p. 37.
} 
na sociedade brasileira. ${ }^{25}$ Rosana da Câmara Teixeira acredita que "as situações-limite de violência podem indicar insatisfações existentes na sociedade que revelam certas visões sobre a mesma por parte desses indivíduos". A mesma autora propõe compreender a violência dos torcedores "articulada a uma reflexão sobre as diferentes práticas de violência existentes em nossa sociedade". ${ }^{26}$ Wisnik considera que, "nesta luta-de-morte simulada ou real em que o ataque à figura do inimigo é um atentado à própria precariedade da autoimagem", pode-se reconhecer a "maquete viva de um estado de coisas que o mundo nos apresenta de muitas formas, em muitos níveis, e em muitas áreas da existência".27

\section{Segundo tempo: vigiando a paixão}

A bibliografia referente ao policiamento das torcidas é escassa e quase inexistente. ${ }^{28}$ A pioneira e mais importante contribuição foi a obra de Maurício Murad. Embora os primeiros estudos e pesquisas tenham sido realizados por ele desde a primeira metade da década de 1990, ${ }^{29}$ iremos dialogar com dois livros que ele publicou recentemente e que contêm suas principais conclusões acerca do tema. Serão comentados tão somente os trechos que tratam do policiamento e da legislação, pois estão intimamente relacionados.

Em A violência e o futebol, após uma comparação com o que ocorreu e ocorre em outros países (Inglaterra, Itália, Espanha, Portugal, dentre outros), Murad realizou uma série de propostas para diminuir a violência relacionada ao futebol. No que diz respeito ao policiamento, elas são as seguintes:

- reuniões periódicas das polícias com as torcidas organizadas;

- delegacia móvel nos estádios;

- leis específicas com punição rigorosa para delitos cometidos no interior e nas proximidades dos estádios;

- circuito interno de televisão;

- policiamento à paisana infiltrado nas organizadas;

- criação de polícias especializadas (como o GEPE);

- revista rigorosa e permanente de torcedores;

- responsabilização penal dos pais ou responsáveis de menores infratores;

- proibição de comparecimento aos estádios do torcedor violento;

- multiplicação das penas alternativas e dos trabalhos reeducativos. ${ }^{30}$

\footnotetext{
${ }_{25}^{25}$ aurício Murad, A violência no futebol, São Paulo, Saraiva, 2012, p. 29.

${ }^{26}$ /bidem, p. 179.

${ }^{27} / \mathrm{bidem}$, p. 54. A este respeito poderíamos utilizar o conceito de 'violência estrutural', presente no mundo contemporâneo, caracterizado por Milton Santos: "a violência estrutural resulta da presença e das manifestações conjuntas, nessa era de globalização, do dinheiro em estado puro, da competitividade em estado puro e da potência em estado puro, cuja associação conduz à emergência de novos totalitarismos e permite pensar que vivemos numa época de globaritarismo muito mais do que de globalização". Milton Santos, Por uma outra globalização - do pensamento único à consciência universal. 6. ed., Rio de Janeiro, São Paulo, Record, 2001. p. 55. ${ }^{28}$ A obra de Maurício Murad (A violência no futebol, São Paulo, Saraiva, 2012) 25 e um livro anterior do mesmo autor (A violência e o futebol: dos estudos clássicos aos dias de hoje, São Paulo, FGV, 2007) são as principais referências. Mais recentemente, foi defendida uma Tese de Doutorado em Antropologia que abordou brevemente o tema do policiamento: Martin Christopher Curi Spörl, Espaços da emoção: arquitetura futebolística, torcida e segurança pública, Niterói, Programa de Pós-Graduação em Antropologia e Ciência Política, Universidade Federal Fluminense, 2012.

${ }^{29}$ Murad criou o Núcleo de Sociologia do Futebol na Universidade do Estado do Rio de Janeiro em maio de 1990 e lançou o número zero da revista Pesquisa de Campo, em julho de 1994.

${ }^{30}$ Mauricio Murad, A violência e o futebol: dos estudos clássicos aos dias de hoje, São Paulo, FGV, 2007, p. 63-64. Para um livro similar, em que há propostas de medidas de segurança a serem tomadas para coibir a violência nos estádios, a partir de uma comparação com o caso espanhol, ver Heloisa Helena Baldy dos Reis, Futebol e Violência, Campinas, Armazém do Ipê, Autores Associados, 2006.
} 
Vale notar que além das propostas, muitas delas já implementadas em estádios, o livro não se dedicou a uma análise da ação policial concreta, de fato existente.

Em A violência no futebol, há mais menções à polícia: cita-se a corrupção policial e o descrédito da Polícia Militar no Rio de Janeiro. ${ }^{31}$ Mesmo assim, é possível afirmar que, para o autor, a polícia é um fator de diminuição da violência por meio da repressão e do diálogo. Salientando o pioneirismo e a enorme contribuição de Murad a este debate, pode-se propor uma possibilidade complementar: da polícia como alimentadora e muitas vezes causadora da violência nos estádios e em torno deles. É preciso estudar de que forma leis e propostas são colocadas em prática, na relação efetiva entre policiais e torcedores.

Tendo como base o trabalho de campo desenvolvido no projeto A Paixão Vigiada: o policiamento de torcedores no Brasil e na Inglaterra, ${ }^{32}$ enfatizamos as conclusões referentes à etapa brasileira, mas realizando breves comparações com o que foi observado na Inglaterra. ${ }^{33}$

O trabalho de campo começou com uma ida ao GEPE e de um contato com seu comandante, o Major Marcelo Pessoa, que autorizou a pesquisa e aceitou conceder uma entrevista duas semanas depois. ${ }^{34}$ À época, ele já estava à frente do GEPE há três anos. Segundo o mesmo, quando assumiu a tropa de tal grupo, a mesma era problemática, coalhada de policiais violentos, que viam o torcedor como ini-

Ao invés de perceber a violência das tor-
cidas como fruto de patologias individu-
ais ou coletivas, é preciso entendê-la como
uma linguagem

migo e vice-versa. A polícia "metia a porrada mesmo" e havia confrontos cada vez mais violentos entre as torcidas e entre estas e a polícia. Sua gestão começou com um "choque", pois ele retirou dez policiais do efetivo (entre praças e oficiais) e passou a recrutar outros com ficha limpa e dispostos a trabalhar com a sua filosofia: "menos porrada e mais resultado operacional" (detenções, indiciamentos, apreensões). Admite, todavia, que de vez em quando é necessário "dar uma bastonada" em cumprimento da lei.

\footnotetext{
${ }^{31}$ Mauricio Murad, A violência no futebol, São Paulo, Saraiva, 2012, p. 43-45.

${ }^{32}$ A parte referente ao Brasil foi efetuada entre 2005 e 2007. Para 2007, houve a ajuda de três bolsistas de iniciação científica: Flávio Amieiro, Isabella Trindade Menezes e Natasha Schumack. Cada pesquisador ficou encarregado de realizar o trabalho de campo em uma torcida dos quatro grandes clubes cariocas: Flamengo, Vasco, Fluminense e Botafogo. A pesquisa na Inglaterra (Escócia e Gales) ocorreu durante a temporada de 2007 e 2008. Esta etapa internacional contou com bolsa da Coordenação de Aperfeiçoamento de Pessoal de Nível Superior (Capes), a quem agradeço. Alguns resultados da pesquisa foram publicados em um artigo intitulado “O esporte que vendeu a sua alma”, Revista Piauí, Rio de Janeiro, n. 15, dez. 2007, p. 66-71, disponível em <http://bit.ly/MrAewE>, acesso em 5 de janeiro de 2012.

${ }^{33}$ Foi elaborado um artigo comparativo das práticas de policiamento no Brasil e na Inglaterra, a ser publicado nos anais do "Segundo Simpósio Internacional sobre Hooliganismo e Copa de 2014", ocorrido na Fundação Getúlio Vargas do Rio de Janeiro entre 24 e 25 de abril. Este será denominado "A madeira da lei: gerir ou gerar a violência nos estádios brasileiros?", a ser publicado em Heloisa Baldy dos Reis e Bernardo Borges Buarque de Hollanda (orgs.), Hooliganismo e Copa de 2014: anais do II Simpósio Internacional, Rio de Janeiro, 7 Letras, 2013.

${ }^{34} \mathrm{~A}$ entrevista ocorreu em 17 de maio de 2005. As conversas com o major, todavia, deram-se também antes e depois da entrevista e as passagens foram obtidas em diversos tipos de situações: em diálogos dentro e fora do GEPE, antes, durante e depois das partidas nas quais realizei trabalhos de campo. Gostaria de agradecer ao Major Pessoa pela gentil acolhida à minha pessoa e à pesquisa e pela permissão para que eu realizasse trabalho de campo junto à tropa do GEPE.
} 
Em seguida, Pessoa afirmou que o GEPE se tornou tão respeitado que havia uma lista de 500 policiais querendo nele ingressar. Queixou-se do efetivo de apenas “70 homens e 4 oficiais", quando seriam necessários pelo menos 250, já que o grupo cumpria outras tarefas como o policiamento de ônibus.

Ele declarou ainda que a primeira reunião que marcou com as torcidas foi uma decepção, pois elas "saíram na porrada". Passou então a convocar as torcidas do mesmo time, mas também não teve um bom resultado: duas delas brigaram entre si. A partir daí ele passou a conversar com cada uma separadamente. Começou a cadastrá-las, pedindo que trouxessem nomes, carteira de identidade, CPF e fotos dos componentes. Em seguida, foram colocadas punições relacionadas ao caráter festivo das organizadas: cometeu uma infração (um ato violento), a torcida fica sem a faixa, na próxima sem instrumentos, sem bandeira etc.

Quanto à sua filosofia de trabalho, afirmou ter havido uma grande transformação em relação ao que existia antes:

O GEPE tinha um cunho de polícia de choque, de força de choque, de combate, e nós implantamos o sistema de policiamento comunitário, uma ideia diferente: dentro de uma tropa repressiva nós colocamos um policial preventivo, transformamos um policial repressivo num policial preventivo.

A implantação do policiamento comunitário teria visado, segundo o Major, solucionar os inúmeros problemas do abuso de autoridade, agressão e violência. Ele teria examinado os perfis de cada um dos seus comandados, direcionando aqueles mais violentos para serviços tranquilos, evitando que trabalhassem diretamente no estádio, uma tarefa considerada estressante. Escalou policiais que torcem para um time para tirar serviço junto aos torcedores do seu time, pois anteriormente os profissionais batiam em torcedores do time adversário e pensavam: "Ah, eles são vascaínos (ou rubro-negros, ou tricolores, ou botafoguenses)".

O resultado teria sido o estabelecimento de uma relação de confiança entre torcedores e policiais e a ausência de ocorrências graves nos últimos dois anos. Evangélico, assim como afirma ser toda a sua família, em sua mesa ele tem um exemplar da Bíblia, aberta no Salmo 91, cujo versículo 7 faz questão de me recitar: "Mil cairão a teu lado e dez mil à tua direita, mas não chegará a ti".

O trabalho do GEPE teria dois pilares. No dia do jogo, haveria um grupo de quatro policiais junto de cada torcida, funcionando como termômetro, monitorando-a e efetuando prisões imediatas ou chamando reforço quando necessário. Eles seriam a "célula nervosa", composta de "policiais comunitários", conhecidos e respeitados pelas torcidas e escolhidos a dedo pelo major entre os seus homens mais equilibrados, com melhor perfil. $\mathrm{O}$ outro pilar se assentaria no uso de informantes para ficar sabendo dos confrontos com antecedência.

Confesso que parti para o trabalho de campo propriamente dito com a melhor das impressões acerca do trabalho do GEPE. Infelizmente, na prática, a teoria é outra e o quadro que encontrei diferia muito das intenções e avaliação realizadas pelo comandante da unidade.

As condições de trabalho dos policiais eram bastante ruins. $\mathrm{O}$ banheiro do GEPE, quando lá estive, era nauseabundo. Nas conversas entre eles, o 
tema dos baixos salários e de uma possível greve era constante. Um deles comentou com ironia que o policial militar entra na corporação a partir de uma mentira: é anunciado um salário de $\mathrm{R} \$ 1.203,00$, mas recebe-se apenas $\mathrm{R} \$$ 800,00 . Doutra feita um policial do GEPE reclamou com os colegas que não tinha dinheiro nem para comprar "um barraco" em uma favela muito distante do centro. Quando questiono-os como arranjar um lugar para morar sem ser policial, ele gesticula usando as mãos para tapar sucessivamente os olhos, os ouvidos e a boca. Afirmaram que passam pelos "caras", ou seja, os bandidos, e o cumprimenta com bom-dia, para não conversar. Reclamam também do hospital da corporação, dizendo ser necessário chegar horas antes para conseguir marcar consulta. Outro assunto preferido: fuzis e armamentos, com intermináveis discussões acerca da classificação e características de cada arma, sem falar nas preferências de cada um. Também reclamam da corrupção na política e na alta hierarquia da polícia.

Um desses profissionais não parava de brincar com os colegas, satirizando a condição dos mesmos, dizendo que filho de policial militar está sempre 'chorando e com nariz escorrendo'. Mudando de tom, elogia a temida polícia de Israel, que, segundo ele, "sai matando todo mundo quando há um sequestro, mesmo que tenham que morrer civis. Assim, os terroristas ficam

\section{Escalou policiais que torcem para um time para tirar serviço junto aos torcedores do seu time, pois anteriormente os profissionais batiam em torcedores do time adversário}

com medo de sequestrar". No entanto, ele diz saber que não pode ser assim por aqui.

Certa vez, quando viajava no ônibus juntamente com os praças, fiquei surpreso porque o policial que estava sentado no mesmo banco que eu deu um salto em direção à janela com a arma apontada e mandou seus colegas se abaixarem. Passávamos em frente a uma favela. Mas o episódio ficou marcado como um símbolo do que é ser policial no Rio de Janeiro ou do GEPE: significa viver sob forte e ininterrupta tensão.

Um dos soldados com quem conversei antes de um jogo era um jovem na faixa etária dos 20 anos, bem humorado e conhecido entre os colegas como um sujeito que "não esquenta com nada". Para ele, o problema das torcidas estaria nos jovens de 15 a 17 anos: "se acham e querem bater nos outros, mas aí", diz sorrindo, "a gente dá uma porrada neles e eles acalmam". A este respeito, certo dia chegou no quartel do GEPE gabando-se do fato de ter mandado fabricar um cassetete de madeira especial, de maçaranduba: "dói pra cacete".

Além dos diálogos diretos, também acabava entreouvindo conversas importantes, como a de um sargento a gabar-se da sua 'severidade'. Segundo o mesmo, quando liderou o GEPE em um jogo do Flamengo contra o Vasco no campeonato de juniores, avisou para os chefes das torcidas, apontando aos líderes: "se pisarem na bola, vou botar pica em você e você". As reclamações dos torcedores 
não teriam adiantado: o sargento simplesmente proibiu 'tudo': faixas, instrumentos, bandeiras etc. Ao dizerem que queriam falar com o Major Marcelo, teria mandado eles arranjarem seu telefone e eles mesmos ligarem, pois não iria fazê-lo pelo rádio. O referido profissional estava comentando a possível realização de um Flamengo versus Vasco em São Januário. Para ele não haveria problema, era somente usar a sua política de "linha dura" (Figura 1)

Se a distância entre a teoria e a prática do policiamento é enorme quando saímos da sala do comandante, é ainda maior quando examinamos as relações entre policiais e torcedores a partir da visão dos últimos.

Sendo eu mesmo frequentador de estádios há muitos anos, tenho a impressão de que a polícia lida com os torcedores como se estivesse cuidando de gados. Não somente no Rio, mas também em São Paulo, por exemplo. Quando da ida ao Morumbi para assistir a um Corinthians versus Palmeiras em março de 2007, nossa equipe de pesquisadores estava do lado de fora do estádio junto a algumas barracas de comida que vendiam churrasquinho e afins. Como havia uma certa aglomeração de torcedores famintos, as pessoas acabavam por ocupar parte da rua. A solução da Polícia Militar foi enviar soldados a cavalo que se lançam sem aviso sobre a multidão. Nós que tratássemos de sair da rua o mais rapidamente possível (Figura 2). Em torno do Maracanã, em situação similar de estarem pessoas na rua, observa-se policiais militares cutucarem os torcedores com a ponta do fuzil. Exemplo ainda mais chocante vivenciado por mim ocorreu depois da final do campeonato carioca de 2007 entre Flamengo e Botafogo. Tendo o Flamengo se sagrado campeão, sua torcida estava alegre e feliz e era compreensível que demorasse a se afastar do estádio. O clima de festa

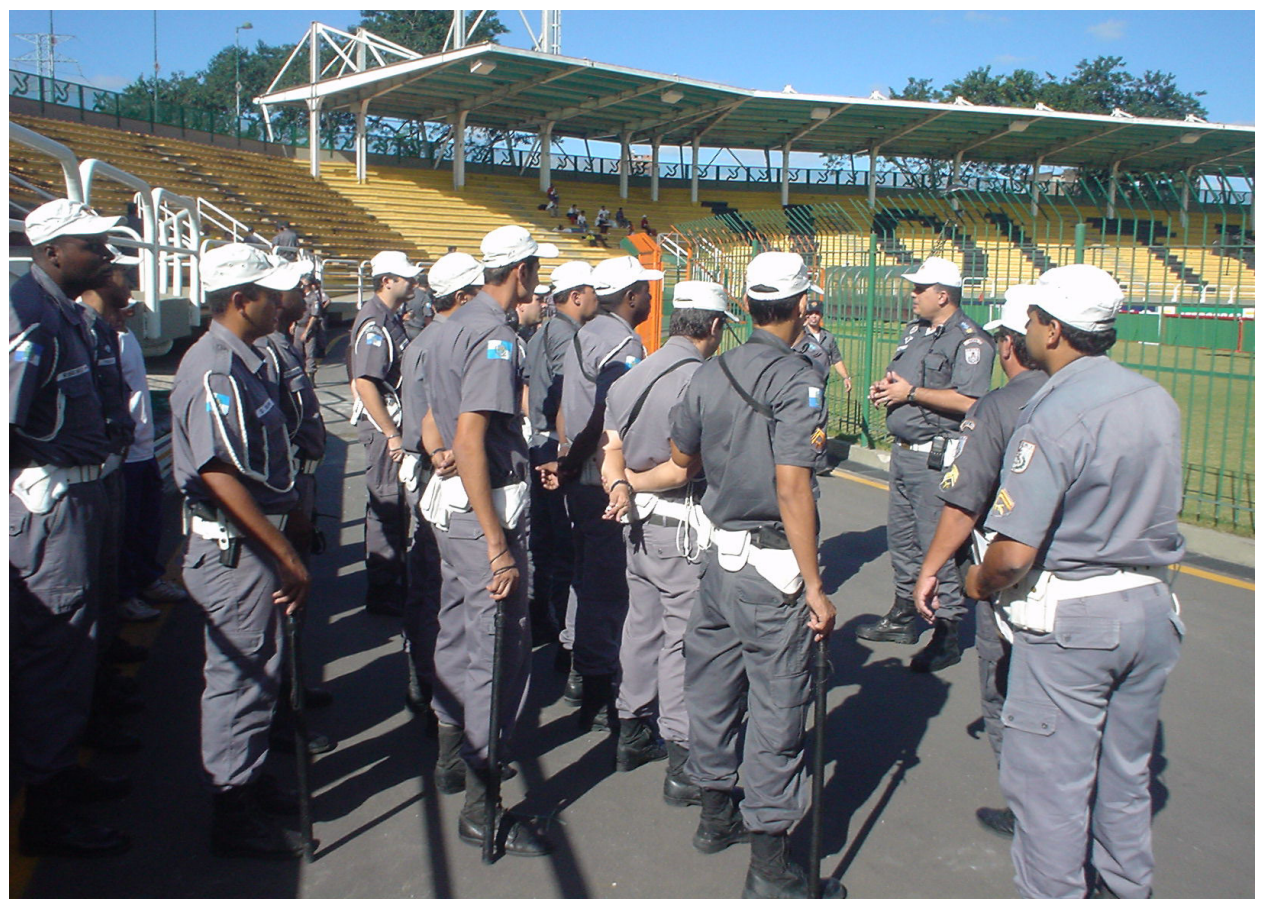

Figura 1. Diante de parte da tropa do GEPE, o Major Marcelo dá suas últimas instruções antes do jogo Flamengo x Fluminense. Estádio da Cidadania, Volta Redonda, 29 de maio de 2005. Foto do autor. 
se dissipou rapidamente quando a polícia passou a utilizar cavalos, gás de pimenta e cassetetes para dispersar os aterrorizados torcedores em meio a gritos e à correria.

Junto às torcidas organizadas, foram coletados relatos bem piores. Um integrante da torcida A revelou que, ao ouvir o nome do Major, seu joelho treme e explica o motivo: os policiais do GEPE costumam bater com o cassetete atrás do joelho, fazendo a pessoa dobrar e ficar à mercê. Outro acusou o Major de ter duas "caras": diante da imprensa pregaria a paz,

\section{Foram presenciadas cenas dantescas: um \\ torcedor com as costas inchadas e roxas, tendo marcas de cassetete; outro sangrando, atingido na cabeça por um policial}

mas mandaria seus soldados "meterem a porrada". O mesmo torcedor diz respeitar o oficial, por ser bom de briga, "sujeito homem". Parece contradição, mas revelou o compartilhamento de uma lógica da masculinidade violenta. Os torcedores apresentam marcas no corpo e cicatrizes obtidas no confronto com rivais ou policiais.

São reportadas histórias de policiais civis e militares a soldo de torcidas rivais, servindo de "segurança", como observado no episódio que iniciou este artigo. Os guardas de São Paulo seriam igualmente brutais:

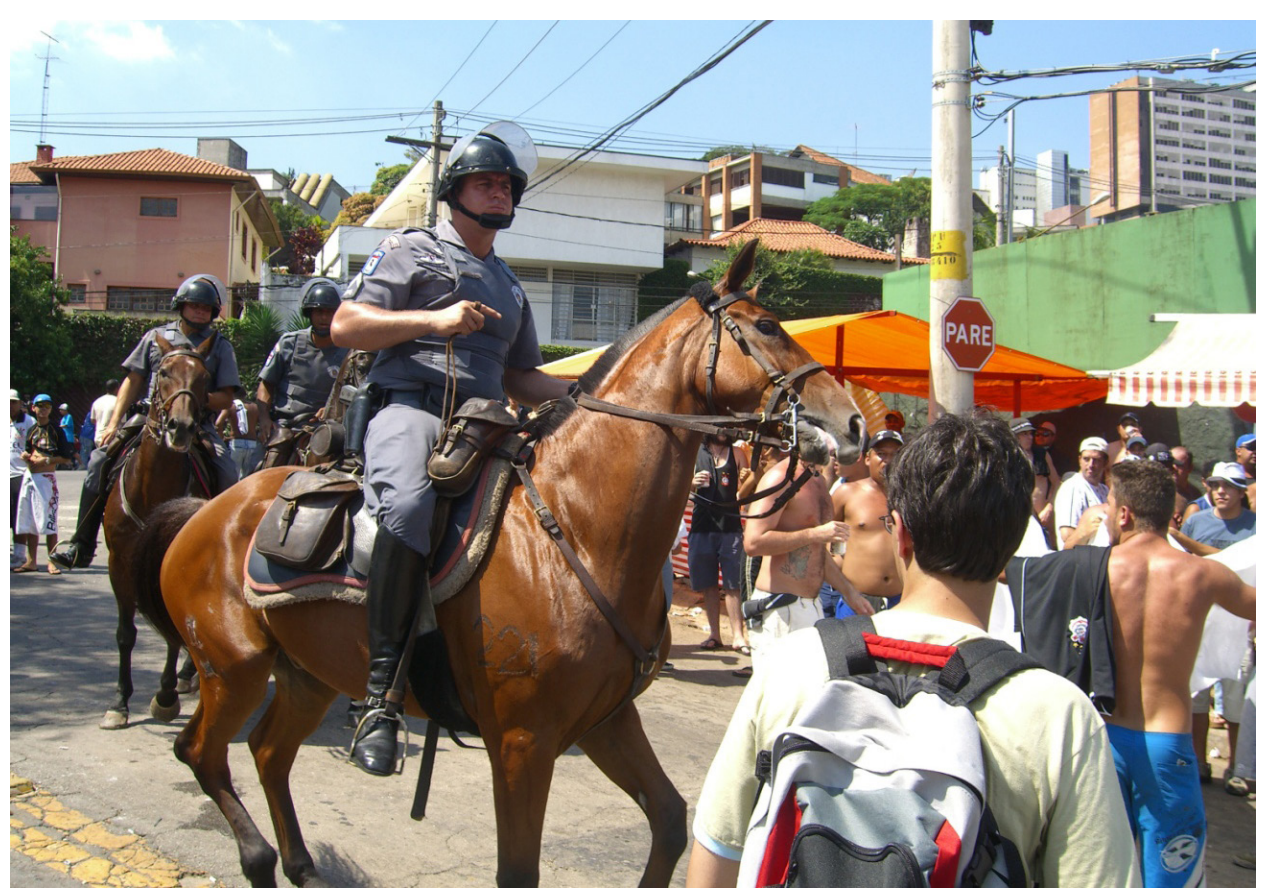

Figura 2. Cavalaria da PM paulista dispersa torcedores sem aviso nas imediações do Estádio do Morumbi, antes do jogo Corinthians x Palmeiras. São Paulo, 4 de março de 2007. Foto do autor. 
batem e cutucam com o cassetete perguntando "Que polícia bate mais: do Rio ou de São Paulo?". A ROTA chega perto e diz, "provocando para poder dar porrada": "Tu é viado". Há também relatos de rixas entre determinados policiais e alguns torcedores, que são "jurados" pelos primeiros.

Nos nossos diários de campo, há inúmeras informações do emprego despropositado de violência contra os torcedores. Foram presenciadas cenas dantescas: um torcedor com as costas inchadas e roxas, tendo marcas de cassetete; outro sangrando, atingido na cabeça por um policial e um terceiro caído no chão a ser chutado por um grupo de policiais. Há pouquíssimas anotações acerca de prisões e não presenciei ou ouvi falar de investigações. É uma polícia que antes de tudo bate. Torcedores? Maçaranduba neles! 